\title{
Embryonic and larval development of the soft-shell clam Mya arenaria L., 1758 (Heterodonta: Myidae) in the White Sea
}

\author{
L.P. Flyachinskaya, P.A. Lezin \\ Zoological Institute RAS, Universitetskaya nab., 1, Saint-Petersburg, 199034 Russia. E-mail: \\ Lyudmila.Flyachinskaya@zin.ru
}

\begin{abstract}
Soft-shell clam Mya arenaria L., 1758 is the common bivalve of intertidal communities in the northern hemisphere. In the present paper embryonic and larval development of $M$. arenaria were examined. The timing and characteristics of spawning were studied. The basic stages of development and features of larval morphology at different stages were investigated. Special attention is paid to the structure of the shell and hinge of the larvae of $M$. arenaria.

How to cite this article: Flyachinskaya L.P., Lezin P.A. 2017. Embryonic and larval development of the soft-shell clam Mya arenaria L., 1758 (Heterodonta: Myidae) in the White Sea // Invert. Zool. Vol.14. No.1. P.14-20. doi: 10.15298/invertzool.14.1.03
\end{abstract}

KEY WORDS: embryonic development, larval development, hinge development, Bivalvia, Mya arenaria.

\section{Эмбриональное и личиночное развитие Mya arenaria L., 1758 (Heterodonta: Myidae) в Белом море}

\section{Л.П. Флячинская, П.А. Лезин}

Зоологический институт РАН, Университетская наб., 1, Санкт-Петербург, 199034 Россия. E-mail: Lyudmila.Flyachinskaya@zin.ru

РЕЗЮМЕ: Двустворчатый моллюск Mya arenaria L., 1758 является одним из массовых видов в литоральных сообществах северного полушария. В настоящей работе рассматривается эмбриональное и личиночное развитие мии. Изучены сроки и особенности нереста в природе. Исследованы основные стадии развития и особенности морфологии личинок. Особое внимание уделяется строению раковины и замка личинок M. arenaria.

Как цитировать эту статью: Flyachinskaya L.P., Lezin P.A. 2017. Embryonic and larval development of the soft-shell clam Mya arenaria L., 1758 (Heterodonta: Myidae) in the White Sea // Invert. Zool. Vol.14. No.1. P.14-20. doi: 10.15298/invertzool.14.1.03

КЛЮЧЕВЫЕ СЛОВА: эмбриональное развитие, личиночное развитие, развитие замка, Bivalvia, Mya arenaria. 


\section{Introduction}

Soft-shell clam Mya arenaria Linnaeus, 1758 is one of the commonest bivalves in the boreal regions. This species inhabits intertidal and subtidal soft-bottom flats along virtually all coasts in the northern hemisphere (Hanks, 1963). Despite the large number of studies on the life cycle and spawning of this mollusk, the early development of $M$. arenaria remains poorly explored (Abraham, Dillon, 1986). Larval development is documented fragmentarily, with significant gaps in the description of timing and morphological features of larval stages. Significant discrepancies exist in the descriptions of larval shell and hinge (Jørgensen, 1946; Sullivan, 1948; Loosanoff, Davis, 1963; Chanley, Andrews, 1971). The present paper examines the development of the soft-shell clam Mya arenaria in the White Sea from fertilization to metamorphosis.

\section{Material and Methods}

The studies were performed at the White Sea Biological station Kartesh of the Zoological Institute RAS ( $\left.66^{\circ} 20.230^{\prime} \mathrm{N} ; 33^{\circ} 38.972^{\prime} \mathrm{E}\right)$ in 2000-2014. Larvae and adult animals were collected in the Chupa Inlet near the biological station.

For the study of the early stages of embryogenesis the spawning of mature specimens was induced in the laboratory conditions. Stimulation of spawning was carried out by raising water temperature by $2-3^{\circ} \mathrm{C}$, relative to the temperature in the sea.

Larvae of $M$. arenaria at different developmental stages were obtained from plankton, using a Juday net with a $100-\mu \mathrm{m}$ mesh. The collected larvae were reared in the laboratory. Animals, 1-2 individuals per $1 \mathrm{ml}$ of water, were maintained in plastic containers with constant aeration at temperature and salinity corresponding to those in the sea $\left(11-12.5^{\circ} \mathrm{C}, 24 \%\right)$.

Images of live larvae and shells were made using the microscope MBB-1 and the camera Nikon Coolpix 4500. The study of larval hinge and the structure of the shell were carried out on cleaned valves (Flyachinskaya, Lezin, 2008).

\section{Results}

Spawning of Mya arenaria in the White Sea occurs in summer - early autumn with two peaks: in late June-early July and late August. The diameter of fertilized oocytes is 73 to 76 $\mu \mathrm{m}$. Selection of the first polar body occurs within 10-15 min after fertilization; during 510 min after that the second polar body stands out (Fig. 1A). Within 30 min after fertilization the first polar lobe begins to form, then the first cleavage furrow is forming (Fig. 1B). In 1 hour after fertilization, the formation of two blastomeres occurs (Fig. 1C). The second division takes place within 1.5 hours after fertilization, however the formation of the second polar lobe is not observed. After several successive divisions a blastula consists of 32 blastomeres (Fig. 1D). With further development the blastula forms cilia, and the larva shifts to active swimming.

Larva stays at the blastula stage for a relatively long time: from 4.5 to 15 hours after fertilization. Prototroch cilia are formed only at the 10th hour of development, while at the 12th hour apical tuft appears and photo- and the gravitational taxes begin to work. Caudal tuft is absent in this species (Fig. 1E).

Gastrulation of $M$. arenaria larvae starts in 15-16 hours after fertilization and continues for 1.5-2 hours. Formation of the shell gland begins a little earlier than invagination of archenteron. These processes lead to formation of conchostoma stage (Fig. 1F), which lasts for 10-12 hours.

Approximately a day after fertilization, the eversion of shell gland starts and larva moves to the trochophora stage. The shell begins to form on the dorsal side of the larva (Fig. 1G). At this stage of development the shell is a single twolobed structure. Archenteron is greatly lengthened and bent, velum and digestive system begin to form.

About 1.5 days after fertilization the process leading to the formation of early veliger begins. By this time larva had formed digestive system, however the rear gut has no opening and the larva does not feed. The size of larvae at the early veliger stage is $85-90 \mu \mathrm{m}$. 


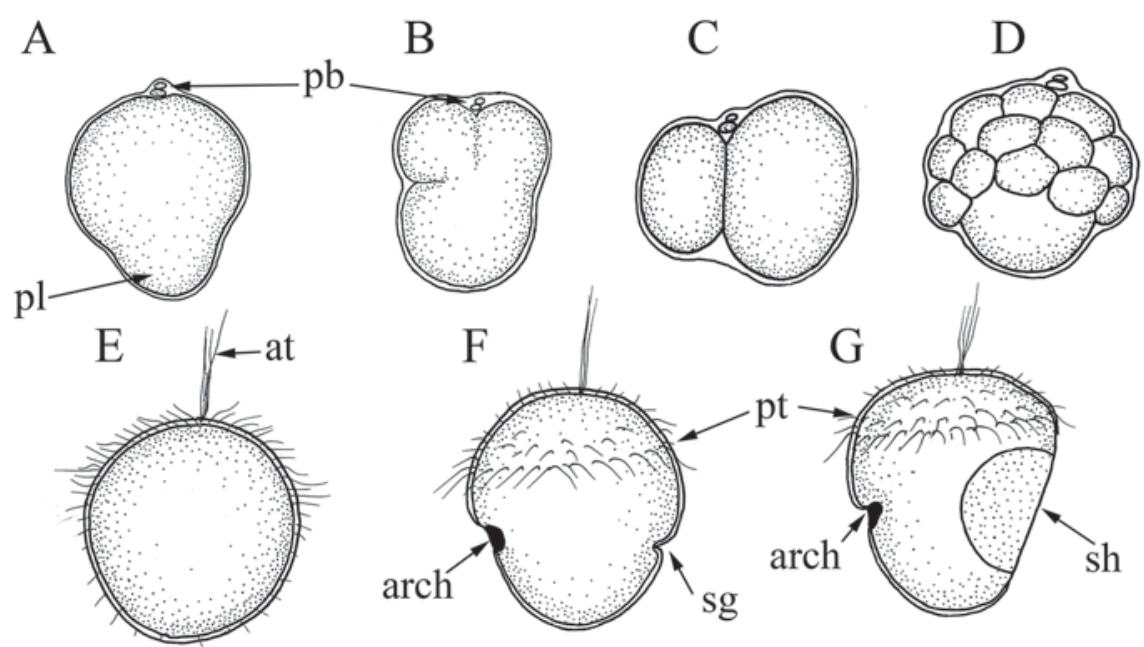

Fig. 1. Cleavage and gastrulation of Mya arenaria.

A - forming of the first polar lobe; B — forming of the first cleavage furrow; C — two blastomeres; D — blastula; E - swimming blastula; F — conchostoma; G — trochophora. Abbreviations: arch — archenteron; at — apical tuft; $\mathrm{pb}$ - polar bodies; pl — polar lobe; pt — prototroch; sg — shell gland; sh — shell.

Рис. 1. Дробление и гаструляция Mya arenaria.

$\mathrm{A}$ - формирование первой полярной лопасти; В - образование первой борозды дробления; С - стадия двух бластомеров; D - бластула; Е - подвижная бластула; F — конхостома; G — трохофора. Обозначения: arch архентерон; at — апикальный султанчик; pb — направительные тельца; pl — полярная лопасть; $\mathrm{pt}$ - прототрох; sg — раковинная железа; sh — раковина.

Two days after fertilization the formation of velum ends, larva has a $\mathrm{D}$-shaped shell and an anterior adductor (Fig. 2A). The larva passes to the stage of veliger; its size reaches 110-120 $\mu \mathrm{m}$. The larva actively moves due to beating of the velum cilia and is able to control its movement by the apical tuft. At this stage the digestive system is fully formed, larva begins to feed. Digestive system of M. arenaria is asymmetric. Digestive gland is shifted to the right, and the esophagus empties into the stomach on the left side. The digestive gland is rich of lipid inclusions and colored in orange or brown.

Veliger of $M$. arenaria has a well-developed muscular system consisting of muscles-retractors of velum, dorsal muscles, pre- and postanal muscles. Thus, larva can pull the velum quickly, and actively move its body inside the shell by pre- and postanal muscles.

On the 15th-17th day of development, when shell reaches a size of $220 \mu \mathrm{m}$, larvae begin to form foot, posterior adductor, rudiments of gills and statocyst. The larva passes to the stage of pediveliger (Fig. 2B). At the size of 230-240 $\mu \mathrm{m}$ larva has posterior adductor and foot. The gill filaments increase. The intestine becomes longer, but in general the digestive system remains almost unchanged. At the stage of pediveliger the byssal gland begins to function.

The larva of $M$. arenaria at the stage of straight hinge has a shell length 130-135 $\mu \mathrm{m}$. The shell is rounded with a slightly pointed anterior end, umbos are not formed (Fig. 3A). Star and radial zones are distinct. The hinge edge is narrow, with small projection and a recess on each valve (Fig. 4A).

When the shell size is $170 \mu \mathrm{m}$, formation of umbos starts (Fig. 3B). Fully formed umbos were reported in larvae with a size of $200 \mu \mathrm{m}$. The proximal edge of the shell is elongated and pointed, the distal and ventral edges are roundish. Ridges and flanges are formed on a periphery of the hinge (one ridge and one flange on each valve) (Fig. 4B). 

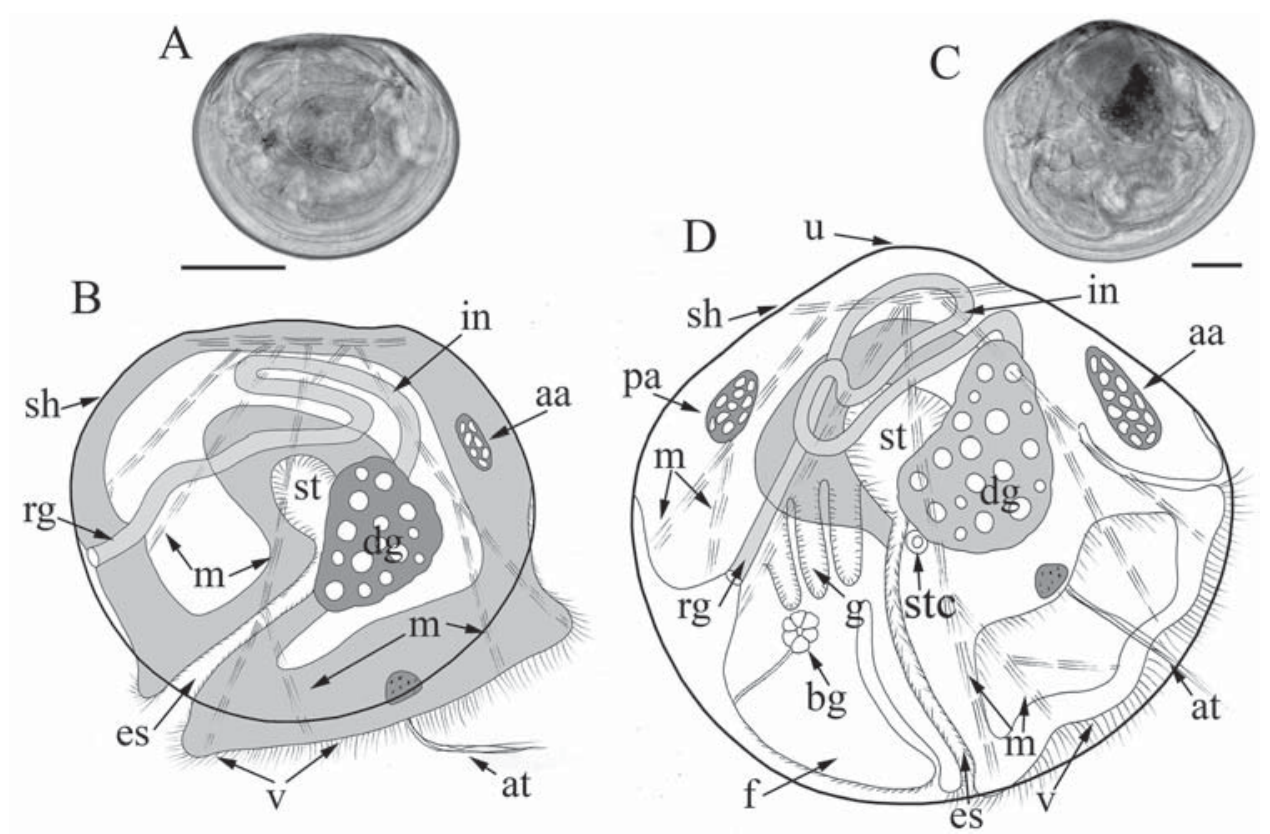

Fig. 2. Anatomy of Mya arenaria larvae. A-B - veliger stage; C-D - pediveliger stage.

$\mathrm{A}$ - photo of live veliger; $\mathrm{B}$ - diagram of veliger anatomy; $\mathrm{C}$ - photo of live pediveliger; $\mathrm{D}$ - diagram of pediveliger anatomy. Abbreviations: aa — anterior adductor; at — apical tuft; bg — byssal gland; dg — digestive gland; es esophagus; $\mathrm{f}$ - foot; $\mathrm{g}$ - gills; in — intestine; $\mathrm{m}$ - muscles; $\mathrm{pa}$ - posterior adductor; $\mathrm{rg}$ - rear gut; sh — shell; st - stomach; stc - statocyst; u - umbo; v - velum. Scale bars - $50 \mu \mathrm{m}$.

Рис. 2. Анатомия личинки Mya arenaria. A-B - велигер; C-D - педивелигер.

A - фотография живого велигера; В - диаграмма анатомии велигера; C - фотография живого педивелигера; $\mathrm{D}$ - диаграмма анатомии педивелигера. Обозначения: aа — передний аддуктор; at — апикальный султанчик; bg - биссусная железа; dg — печень; es — пищевод; f — нога; g — жабры; in - кишечник; $\mathrm{m}$ - мышцы; pa задний аддуктор; $\mathrm{rg}$ — задняя кишка; sh — раковина; st — желудок; stc — статоцист; u — макушка; $\mathrm{v}$ - парус. Масштаб $50 \mu \mathrm{m}$.

Veliger at the size $240 \mu \mathrm{m}$ has the rounded shell with distinct umbos (Fig. 3C). The anterior shoulder is longer. The anterior edge of the shell is somewhat pointed. At the posterior part of provinculum the ligament begins to form (Fig. 4C). The hinge edge has the tooth-like projection and a recess on each valve.

At the stage of 270-280 $\mu \mathrm{m}$ larva has a fully formed larval shell with a slightly pointed anterior edge (Fig. 3D). The umbos are separated and fully formed, anterior shoulder is longer than posterior. Around the perimeter of the shell a mantle line is clearly visible. The ligament continues to evolve; the number of projections on the hinge edges does not change (Fig. 4D).

Before metamorphosis (shell size 300-310 $\mu \mathrm{m})$, the shell acquires a more rounded form, the shoulders become almost equal (Fig. 3E). Growing edge of prodissoconch bears clear concentric striations. Tooth-like projections of the hinge become more complex, but their number remain unchanged (Fig. 4E).

\section{Discussion}

Breeding of the soft-shelled clam usually is timed to the summer season. On the greater part of the distribution range, Mya has two peaks of reproduction: in spring - early summer, and the second peak is usually observed in late summerearly autumn (Battle, 1932; Pfitzenmeyer, 1962; Abraham, Dillon, 1986). In the White Sea larvae of M. arenaria are observed in the plankton from late June to late August-September (Kauf- 

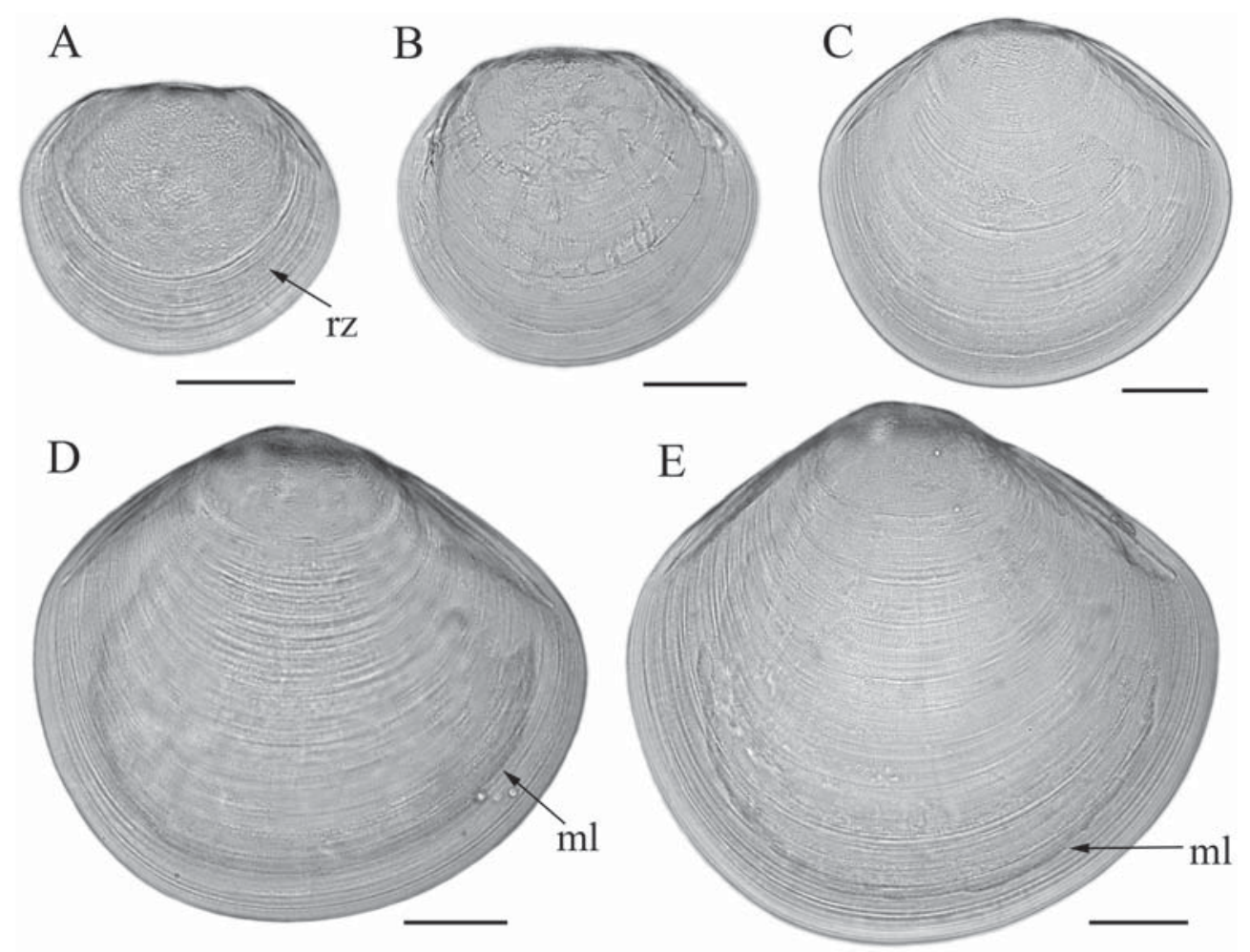

Fig. 3. Larval shell of Mya arenaria at the different stages of development (right valves).

A - straight hinge veliger $(135 \mu \mathrm{m})$; B — veliger $(175 \mu \mathrm{m}) ; \mathrm{C}$ - early pediveliger $(240 \mu \mathrm{m})$; D - pediveliger $(270$ $\mu \mathrm{m}) ; \mathrm{E}$ - pre-metamorphosis stage $(300 \mu \mathrm{m})$. Abbreviations: $\mathrm{ml}$ - mantle line; $\mathrm{rz}$ — radial zone. Scale bars - $50 \mu \mathrm{m}$. Рис. 3. Личиночная раковина Mya arenaria на разных стадиях развития (правые створки).

А — стадия прямого замка (135 $\mu \mathrm{m}) ; \mathrm{B}$ — велигер $(175 \mu \mathrm{m})$; C — ранний педивелигер $(240 \mu \mathrm{m}) ; \mathrm{D}$ — педивелигер $(270 \mu \mathrm{m}) ; \mathrm{E}$ - предметаморфозная личинка $(300 \mu \mathrm{m})$. Обозначения: $\mathrm{ml}$ - мантийная линия; $\mathrm{rz}$ - радиальная зона. Масштаб $50 \mu \mathrm{m}$.

man, 1977; Günther, Fedyakov, 2000), which agrees well with our data.

The initial stages of $M$. arenaria cleavage are typical for the development of marine bivalves of subclasses Heterodonta and Pteriomorphia (Medvedeva, Malakhov, 1983; Malakhov, Medvedeva, 1985a, b, 1986, 1991; Malakhov et al., 1989). Malakhov and Medvedeva (1985a, 1986, 1991) suggested that the presence or absence of polar lobes in development has a systematic value. Mollusks of subclass Filibranchia (in modern taxonomy, it corresponds to subclass Pteriomorphia - see Bouchet et al., 2010) form polar lobes, whereas in the development of subclass Eulamellibranchia (in the modern taxonomy are subclasses Hetero- donta and Palaeoheterodonta, see Bouchet et al., 2010) polar lobes do not exist. According to our data in development of $M$. arenaria (subclass Heterodonta) formation of the polar lobe was recorded, which contradicts the hypothesis Malakhov and Medvedeva (1985a, 1986, 1991).

The cleavage can be described as heteroquadrant, spiral and asynchronous. This type of cleavage is a characteristic feature of all Autobranchia (Ivanova-Kazas, 1977). The cleavage leads to the formation of blastula, which can be classified as sterroblastula type, because it lacks the inner cavity. This confirms the idea that sterroblastula is a characteristic feature of marine bivalves (Malakhov, Medvedeva, 1991). 

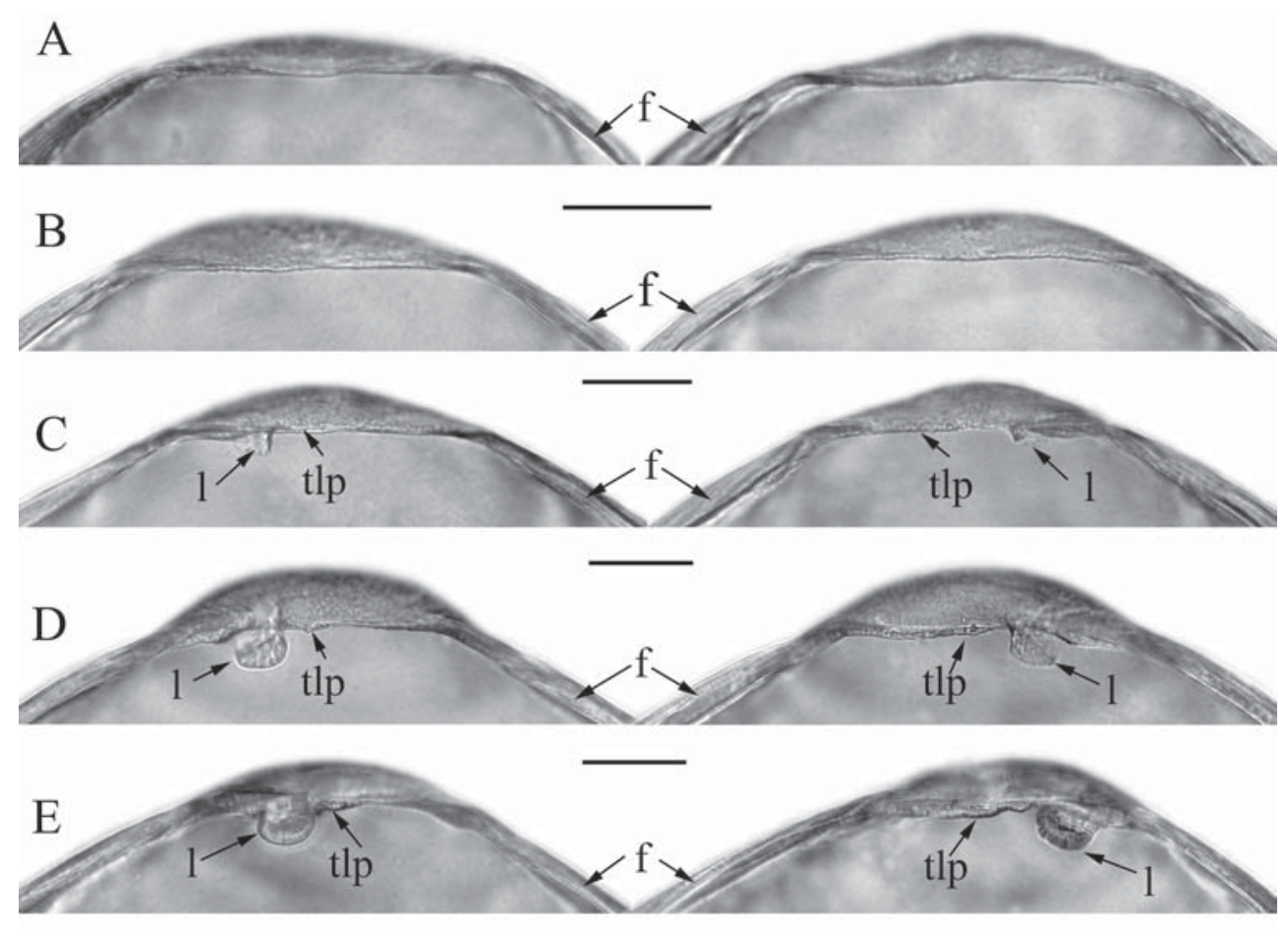

Fig. 4. Larval hinge of Mya arenaria at the different stages of development.

A - straight hinge veliger $(140 \mu \mathrm{m})$; B — veliger $(180 \mu \mathrm{m}) ; \mathrm{C}$ - early pediveliger $(230 \mu \mathrm{m})$; D - pediveliger $(280$ $\mu \mathrm{m})$; E - pre-metamorphosis stage $(310 \mu \mathrm{m})$. Abbreviations: $\mathrm{f}$ - flanges; 1 - ligament; tlp - tooth-like projection. Scale bars $-25 \mu \mathrm{m}$

Рис. 4. Личиночный замок Mya arenaria на разных стадиях развития.

A — стадия прямого замка $(140 \mu \mathrm{m}) ; \mathrm{B}$ - велигер $(180 \mu \mathrm{m}) ; \mathrm{C}$ - ранний педивелигер $(230 \mu \mathrm{m}) ; \mathrm{D}$ - педивелигер $(280 \mu \mathrm{m}) ; \mathrm{E}$ - предметаморфозная личинка $(310 \mu \mathrm{m})$. Обозначения: $\mathrm{f}$ - фланцы; 1 - лигамент; tlp — зубовидные выступы. Масштаб $25 \mu \mathrm{m}$.

Gastrulation is accomplished by invagination and is accompanied by formation of the shell gland, leading to the formation of conchostoma (Malakhov, Medvedeva, 1991). Completion of the shell gland eversion process marks the transition of larvae to the trochophora stage. Morphological structure of larvae at this stage of development is typical for the shelled trochophora.

Digestive system of $M$. arenaria is asymmetric, which has been found also in some other bivalves (Kasyanov et al., 1998). General structure of veliger and pediveliger of Mya is typical for pelagic larvae of bivalves (Waller, 1981; Kasyanov et al., 1998).
The descriptions of shell shape of $M$. arenaria larvae are somewhat contradictory. The majority of authors described a rounded shape with a pointed and elongated anterior edge (Chanley, Andrews, 1971; Kulikova, Kolotukhina 1989; Kasyanov et al., 1998). However, Sullivan (1948) characterized larval shell of Mya as symmetrical, with equal length of shoulders. Our data show that throughout the most part of the development the shell has pointed and elongated anterior edge. Before metamorphosis the shoulders are almost equal and the shell acquires a rounded shape.

The size of $M$. arenaria metamorphosis is highly variable (Jørgensen, 1946). According 
to the literature, the size at metamorphosis ranges from 175 to $300 \mu \mathrm{m}$ (Yoshida, 1938; Sullivan, 1948; Loosanoff, Davis, 1963; Chanley, Andrews, 1971). In the White Sea metamorphosis of Mya areanria occurs at 300-310 $\mu \mathrm{m}$, which represents the upper limit of variation and comparable with the that observed in North Atlantic region (Jørgensen, 1946).

Many researchers noted the weak differentiation of larval hinge elements of $M$. arenaria (Jørgensen, 1946; Rees, 1950; Kasyanov et al., 1998). In some publications the structure of hinge was described as a single tooth on each valve (Kulikova, Kolotukhina 1989; Kasyanov et al., 1998), but in other studies hinge structures were defined as small projections (Rees, 1950). Jørgensen noted a complete lack of differentiation of the teeth (Jørgensen, 1946). Our data also do not allow defining hinge structures as hinge teeth, the observed structures are toothlike projections, but not separate teeth.

\section{References}

Abraham B.J., Dillon P.L. 1986. Species profiles: life histories and environmental requirements of coastal fishes and invertebrates (Mid-Atlantic) - Softshell clam // U.S. Fish. Wildl. Serv. Biol. Rep. Vol.82. 18 p.

Battle H.I. 1932. Rhythmic sexual maturity and spawning of certain bivalve mollusks // Contributions to Canadian Biology and Fisheries. Vol.7. No.1. P.255-276.

Bouchet Ph., Rocroi J.P., Bieler R., Carter J.G., Coan E.V. 2010. Nomenclator of Bivalve Families with a Classification of Bivalve Families // Malacologia. Vol.52. No.2. P.1-184.

Chanley P., Andrews J.D. 1971. Aids for identification of bivalve larvae of Virginia // Malacologia. Vol.11. P.45-119.

Flyachinskaya L.P., Lezin P.A. 2008. [Development of larvae and juvenile shell of bivalve Hiatella arctica (Linnaeus, 1767) in the White Sea] // Invertebrate Zoology. Vol.5. No.1. P.39-46 [in Russian, with English summary].

Günther C., Fedyakov V.V. 2000. Seasonal changes in the bivalve larval plankton in the White sea // Senckenbergiana Maritima. Vol.30. P.141-151.

Hanks R.W. 1963. The soft-shell clam // U.S. Fish Wildl. Serv. Fish. Circ. Vol.162. 16 p.

Ivanova-Kazas O.M. 1977. Comparative embryology of invertebrates. Trochophorata, Tentaculata, Chaetognatha, and Pogonophora). Moscow: Nauka. 312 p. [In Russian]
Jørgensen C.B. 1946. Reproduction and larval development of Danish bottom invertebrates. Lamellibranchia // Medd. Kromm. Danmarks Fisk Havundersog. Ser: Plankton. Bd.4. P.277-311.

Kasyanov V.L., Kryuchkova G.A., Kulikova V.A., Medvedeva L.A. 1998. Larvae of marine bivalves and echinoderms. Washington: Oxonian Press Pvt. Ltd. 288 p.

Kaufman Z.S. 1977. Sexual cycles and gametogenesis of invertebrates from the White Sea. Leningrad: Nauka. 265 p. [In Russian]

Kulikova V.A., Kolotukhina N.A. 1989. [Pelagic larvae of bivalve mollusks of Sea of Japan]. Vladivostok: Institut Biologii morya DVO RAN. 60 p [In Russian].

Loosanoff V.L., Davis H. 1963. Rearing of bivalve mollusks // Adv. Mar. Biol. Vol.1. P.1-136.

Malakhov V.V., Gareeva R.V., Medvedeva L.A. 1989. [Embryonic and early larval development of bivalve mollusc Callista brevisiphonata (Cardiida, Venerida)] // Zool. Zhurn. Vol.68. No.6. P.130-134 [in Russian, with English summary].

Malakhov V.V., Medvedeva L.A. 1985a. [Embryonic and early larval development of bivalve mollusc Mytilus edulis (Mytilida, Mytilidae)] // Zool. Zhurn. Vol.64. No.12. P.1808-1815 [in Russian].

Malakhov V.V., Medvedeva L.A. 1985b. [Embryonic development of pacific oyster] // Biol. morya. No1. P.45-51 [in Russian].

Malakhov V.V., Medvedeva L.A. 1986. [Embryonic development in the bivalves Patinopecten yessoensis (Pectinida, Pectinidae) and Spisula sachalinensis (Cardiida, Mactridae)] // Zool. Zhurn. Vol.65. No.5. P.732-740 [in Russian].

Malakhov V.V., Medvedeva L.A. 1991. Embryonic development of bivalve molluscs: normal and under heavy metal effects. Moscow: Nauka. 132 p [In Russian].

Medvedeva L.A., Malakhov V.V. 1983. [Embryonic development of bivalve mollusc Mactra chinensis (Cardiida, Mactridae)] // Zool. Zhurn. Vol.62. No.8. P.1162-1169 [in Russian].

Pfitzenmeyer H.T. 1962. Periods of spawning and setting of the soft-shelled clam, Mya arenaria, at Solomons, Maryland // Chesapeake Science. Vol.3. P.114-120.

Rees C.B.1950. The identification and classification of Lamellibranch larvae // Hull Bulletins of Marine Ecology. Vol.3. No.19. P.73-104.

Sullivan C.M. 1948. Bivalve larvae of Malpeque bay, P.E.I. // Fisheries Research Board of Canada. Vol.77. P.1-36.

Waller T.R. 1981. Functional morphology and development of veliger larvae of the european oyster Ostrea edulis Linne. Washington: Smithsonian institution press. $70 \mathrm{p}$.

Yoshida H. 1938. Notes on the veligers and the young shells of Mya arenaria japonica Jay // Venus. Vol.8. No.1. P.13-21.

Responsible editor E.N. Temereva 